\title{
Analisis Geospasial Perubahan Penggunaan Lahan dan Kesesuaiannya Terhadap RTRW Kabupaten Purworejo Tahun 2011-2031
}

\author{
Geospatial Analysis of Land Use Changes in 2008-2013 and Their Suitability to the RTRW of Purworejo \\ Regency in 2011-2031
}

\author{
Virgiawan Aji Saputra, Purnama Budi Santosa \\ Department of Geodetic Engineering, Fakulty of Engineering, Universitas Gadjah Mada, INDONESIA
}

Penulis Korespondensi: Purnama Budi Santosa | Email: purnamabs@ugm.ac.id

Diterima (Received): 28/10/2020 Direvisi (Revised): 15/11/2020 Diterima untuk Publikasi (Accepted): 16/11/2020

\begin{abstract}
ABSTRAK
Kabupaten Purworejo terletak pada jalur lintas selatan di wilayah Jawa Tengah yang menghubungkan Yogyakarta dengan kota-kota lain di wilayah selatan Jawa Tengah seperti Kutoarjo, Kebumen, Purwokerto, serta kota-kota lainnya. Letak Kabupaten Purworejo yang strategis ini berdampak pada dinamika sosial, ekonomi, dan kependudukan, khususnya pertumbuhan wilayah. Berdasarkan fenomena tersebut, penelitian ini bertujuan untuk mengetahui perubahan penggunaan lahan yang terjadi di Kabupaten Purworejo, serta kesesuaiannya dengan Rencana Tata Ruang Wilayah (RTRW) tahun 2011-2031. Metode yang digunakan adalah pendekatan analisis geospasial untuk melakukan analisis spasial-temporal perubahan spasial penggunaan lahan dari tahun 2008 dan 2013 . Hasil analisis perubahan spasial ini kemudian dikorelasiakan dengan peta RTRW Kabupaten Purworejo tahun 2011-2031 untuk mengetahui tingkat kesesuaian pengunaan lahan di Kabupaten Purworejo terhadap RTRW. Hasil penelitian menunjukkan bahwa dalam waktu 5 tahun dari tahun 2008 sampai dengan 2013 terjadi perubahan penggunaan lahan sebesar 0,1\%. Perubahan luas penggunaan lahan terbesar terjadi di Kecamatan Grabag dengan persentase 0,71\%, sedangkan Kecamatan Ngobol, Bener, Gebang, dan Loano bisa dikatakan tidak mengalami perubahan penggunaan lahan. Ditinjau dari kesesuaian penggunaan lahan terhadap RTRW, maka dapat diperoleh informasi bahwa tingkat kesesuaian penggunaan lahan pada tahun 2013 adalah sekitar 62,21\%. Kecamatan Kutoarjo dengan persentase 93,34\% merupakan kecamatan dengan persentase penggunaan lahan terbesar sesuai peruntukannya. Sedangkan Kecamatan Bagelen dengan persentase 38,40\% merupakan kecamatan dengan persentase penggunaan lahan terkecil sesuai peruntukannya.
\end{abstract}

Kata Kunci: Perubahan penggunaan lahan, Rencana Tata Ruang, SIG, analisis kesesuaian lahan, Kabupaten Purworejo

\section{ABSTRACT}

Purworejo Regency is located on the southern route in the Central Java region which connects Yogyakarta with other cities in the southern region of Central Java such as Kutoarjo, Kebumen, Purwokerto, and other cities. The strategic location of Purworejo Regency has an impact on social, economic and demographic dynamics, particularly regional growth. Based on this phenomenon, this study aims to determine changes in land use that occur in Purworejo Regency, as well as its suitability with the 2011-2031 Regional Spatial Plan (RTRW). The method is to use a geospatial analysis approach to conduct spatial-temporal analysis of land use changes from 2008 and 2013.The results of this spatial change analysis are then correlated with the 2011-2031 RTRW map of Purworejo Regency to determine the level of suitability of land use in Purworejo Regency to RTRW. The results showed that within 5 years from 2008 to 2013 there was a change in land use by $0.1 \%$. The largest change in land use area occurred in the Grabag District with a percentage of $0.71 \%$, while the Ngobol, Bener, Gebang, and Loano Districts did not experience any changes in land use. Judging from the suitability of land use against the RTRW, information can be obtained that the level of land use suitability in 2013 was around 62.21\%. Kutoarjo District with a percentage of $93.34 \%$ is a district with the largest percentage of land use according to its allotment. Meanwhile, Bagelen District with a percentage of $38.40 \%$ was a sub-district with the smallest percentage of land use according to its allotment.

Keywords: Landuse change, Spatial Plans, GIS, land suitability analysis, Purworejo Regency

(c) Author(s) 2020. This is an open access article under the Creative Commons Attribution-ShareAlike 4.0 International License (CC BY-SA 4.0). 


\section{Pendahuluan}

Lahan merupakan salah satu kebutuhan manusia karena seluruh kegiatan manusia berlangsung di atas lahan seperti keperluan tempat tinggal, bercocok tanam, dan berlangsungnya berbagai kegiatan ekonomi, politik, serta sosial. Bentuk pemanfaatan lahan yang dilakukan oleh manusia disebut penggunaan lahan. Penggunaan lahan dapat berupa pemukiman, hutan, tegalan, sawah, dan sejenisnya.

Penggunaan lahan bersifat dinamis karena berubah terhadap waktu dan ruang. Perubahan tersebut terjadi sejalan dengan pertumbuhan jumlah penduduk (Kusrini dkk., 2011; Adiyaksa \& Nugroho, 2020) serta dipengaruhi oleh keberadaan pusat-pusat kegiatan publik (Syafitri \& Santosa, 2020). Luas lahan cenderung tidak berubah, namun pertumbuhan penduduk yang pesat dan bertambahnya tuntutan kebutuhan masyarakat akan lahan mengakibatkan terjadinya ketidaksesuaian antara penggunaan lahan dengan rencana peruntukannya (Khadiyanto, 2005), serta dapat mempengaruhi peningkatan nilai tanah (Al-Vatia, \& Djojomartono, 2019; Astrisele \& Santosa, 2019). Oleh karena itu, untuk menjaga agar penggunaan lahan dapat tertata maka diperlukan kegiatan perencanaan penggunaan lahan (Land Use Planning) (Prabowo, 2019). Di sisi lain, pendaftaran tanah yang baik akan memberi kepastian hukum terkait hak atas tanah (Aditya dkk, 2020).

Kabupaten Purworejo merupakan salah satu kabupaten di Jawa Tengah yang mengalami perubahan penggunaan lahan. Sebagian besar perubahan yang terjadi berupa alih fungsi lahan dari pertanian ke non pertanian seperti untuk perumahan dan permukiman (Pemerintah Kabupaten Purworejo, 2018; Iskandar dkk, 2016). Pada tahun 1990-2001, luas lahan permukiman di Kabupaten Purworejo mengalami pertumbuhan sebesar $12,34 \%$ per tahun akibat pertumbuhan penduduk. Selain perubahan alih fungsi lahan, terjadi juga masalah penggunaan lahan terhadap rencana tata ruang wilayah Kabupaten Purworejo. Permasalahan tersebut antara lain penggunaan lahan yang tidak sesuai dengan kemampuan lahannya serta pengalihan guna lahan dari fungsi lindung menjadi fungsi budidaya dan koversi dari lahan pertanian menjadi non pertanian (PT. Firama Citra Utama, 2003).

Beberapa studi menunjukkan bahwa di beberapa kota atau wilayah di Indonesia menunjukkan ketidaksesuaian penggunaan lahan dengan peruntukannya (Iskandar dkk, 2016; Pangulu, 2016; Handayani, 2013; Kusumasari, 2015). Dengan memanfaatkan teknologi penginderaan jauh dan SIG, Iskandar dkk (2016) mengevaluasi kesesuaian penggunaan lahan terhadap peruntukannya di Kecamatan Kutoarjo Kabupaten Purworejo, dan menemukan fakta bahwa $7,65 \%$ dari luasan kecamatan penggunaan lahannya tidak sesuai dengan peruntukannya. Penelitian serupa juga dilakukan oleh Pangulu (2016) yang menunjukkan bahwa luas lahan Kota Bandung mengalami perubahan menjadi lahan industri, perdagangan, dan jasa secara berurutan sebesar $\pm 24 \mathrm{Ha}, \pm 2 \mathrm{Ha}$, dan $\pm 10 \mathrm{Ha}$ pada tahun 2011 - 2015. Perubahan penggunaan lahan yang terjadi masih terdapat ketidaksesuaian dengan Rencana Tata Ruang Wilayah. Persentase perubahan penggunaan lahan yang tidak sesuai dengan Rencana Tata Ruang Wilayah Kota Bandung sebesar 49\%.

Analisis perubahan penggunaan lahan banyak dilakukan dengan menggunakan pendekatan spasial. Seiring dengan perkembangan teknologi satelit penginderaan jauh, metode penginderaan jauh banyak dilakukan karena memiliki beberapa kelebihan seperti cakupan yang luas, informasi yang beragam, serta resolusi citra satelit yang semakin baik (Santosa, 2016). Citra satelit banyak dimanfaatkan untuk menganalisis informasi tutupan lahan (land cover). Informasi tutupan lahan multi temporal (waktu jamak) dapat dimanfaatkan untuk mengetahui perubahan spasial tutupan lahan atau penggunaan lahan (landuse). Selanjutnya, analisis perubahan penggunaan lahan ini digunakan untuk mengevaluasi pertumbuhan suatu wilayah, serta kesesuainanya dengan rencana tata ruang (Prabowo, 2019; Adiyaksa \& Nugroho, 2020; Iskandar dkk 2016). Untuk keperluan tersebut, analisis spasial berbasis Sistem Informasi Geografis (SIG) menunjukkan efektifitasnya di dalam pengolahan data untuk melihat kesesuaian antara perubahan spasial dan dengan rencana tata ruang wilayah (Pangulu, 2016; Prabowo, 2019; Syafitri \& Santosa, 2020).

Mengacu pada laporan mengenai pertumbuhan wilayah Purworejo, di mana terjadi alih fungsi lahan di beberapa wilayah di Kabupaten Purworejo (Pemerintah Kabupaten Purworejo, 2018; Iskandar dkk, 2016; PT. Firama Citra Utama, 2003), serta mengacu pada penelitian sebelumnya yang dilakukan oleh Saputra (2019), maka penelitian ini bertujuan untuk mengetahui perubahan penggunaan lahan yang terjadi di Kabupaten Purworejo, serta kesesuaiannya dengan Rencana Tata Ruang Wilayah (RTRW) tahun 2011-2031. Penelitian ini dilakukan atas dasar adanya peraturan daerah Kabupaten Purworejo Nomor 2 tahun 2011 tentang Rencana Pembangunan Jangka Menengah Daerah (RPJMD) Kabupaten Purworejo tahun 2011-2015. Durasi waktu yang digunakan adalah dari tahun 2008 dan 2013 dengan alasan bahwa data yang digunakan masuk dalam lingkup tahun Rencana Pembangunan Jangka Menengah Daerah (RPJMD) Kabupaten Purworejo yaitu tahun 2011-2015. Antara tahun 2008 sampai 2013 tersebut disinyalir terjadi dinamika perubahan penggunaan lahan di Kabupaten Purworejo yang cukup dinamis. 


\section{Data dan Metodologi}

\subsection{Data dan Lokasi}

Penelitian dilaksanakan di Kabupaten Purworejo, Provinsi Jawa Tengah. Kabupeten Purworejo (Gambar 1) secara geografis terletak antara $109^{\circ} 47^{\prime 2} 28^{\prime \prime}$ BT hingga $110^{\circ} 8^{\prime} 20^{\prime \prime}$ BT dan $7^{0} 32^{\prime}$ LS hingga $7^{\circ} 54^{\prime}$ LS dengan luas sebesar 1.034,817 km2. Kabupaten Purworejo memiliki 16 kecamatan dan 25 kelurahan.

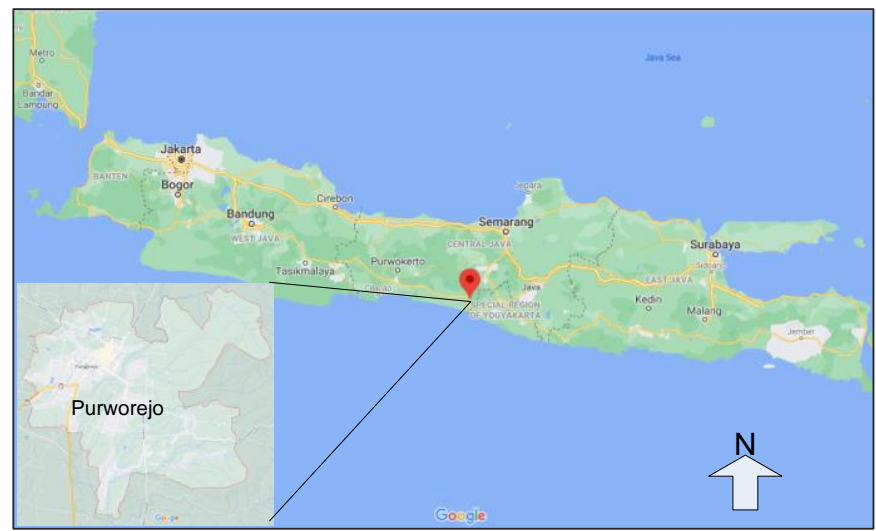

Gambar 1. Lokasi penelitian (Sumber: Google Maps).

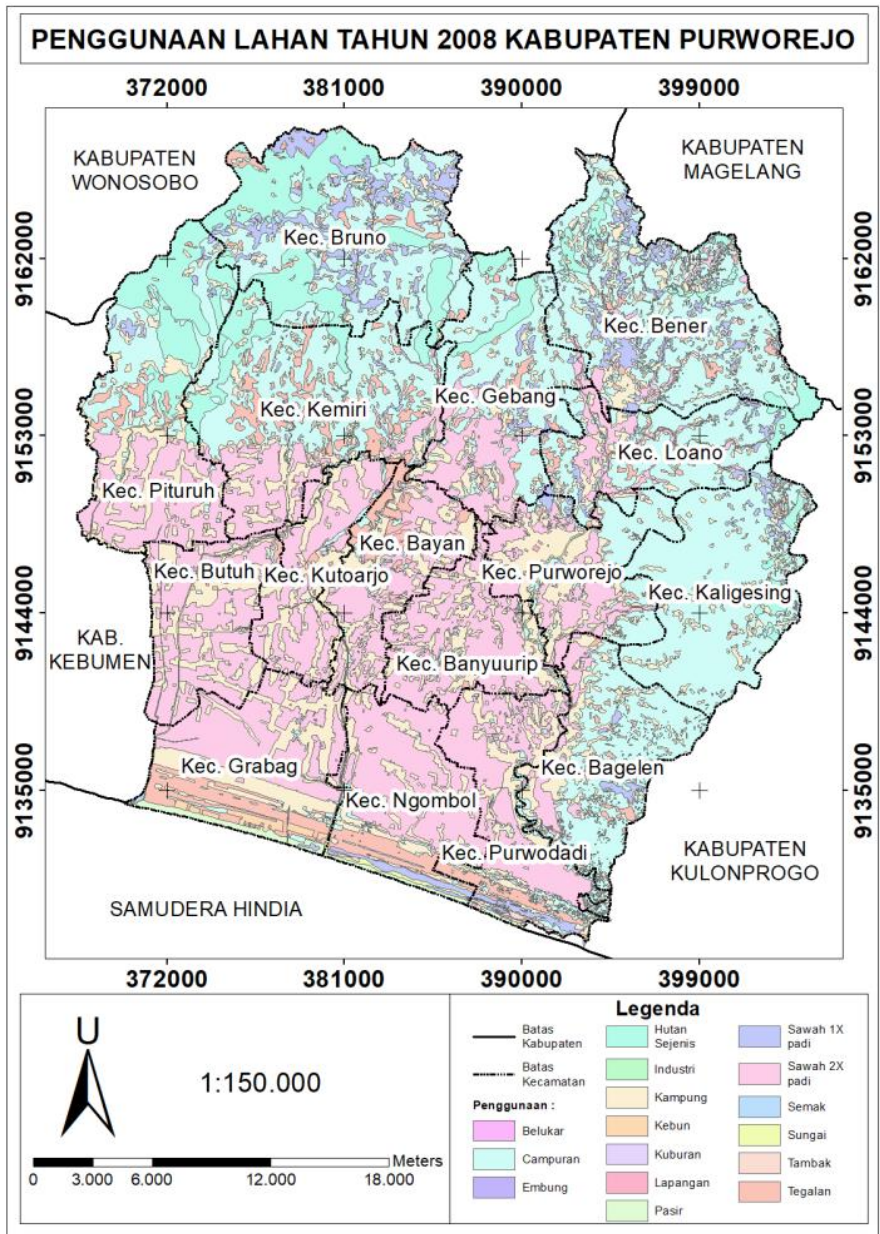

(A)
Secara geografis, Kabupaten Purworejo berbatasan dengan beberapa kabupaten, yaitu Kabupaten Kebumen di sebelah barat, Kabupaten Magelang dan Kabupaten Wonosobo di sebelah utara, Kabupaten Kulonprogo di sebelah timur, dan Samudera Hindia di sebelah selatan.

Data yang digunakan dalam penelitian ini adalah informasi geospasial dengan tema penggunaan lahan Kabupaten Purworejo tahun 2008 dan 2013 (Gambar 2), serta batas administrasi Kabupaten Purworejo. Semua data tersebut dalam format Shapefile yang diperoleh dari Kantor Pertanahan Kabupaten Purworejo. Sistem proyeksi yang digunakan adalah sistem proyeksi Universal Transverse Mercator (UTM), datum WGS 1984, dan zona 49S. Data peta Rencana Tata Ruang Wilayah (RTRW) Kabupaten Purworejo dalam format Shapefile diperoleh dari Dinas Pekerjaan Umum dan Penataan Ruang Kabupaten Purworejo. Data tersebut dalam sistem proyeksi Universal Transverse Mercator (UTM), datum WGS 1984, dan zona 49S yang diperoleh dari turunan citra gabungan kementerian PU tahun 2010.

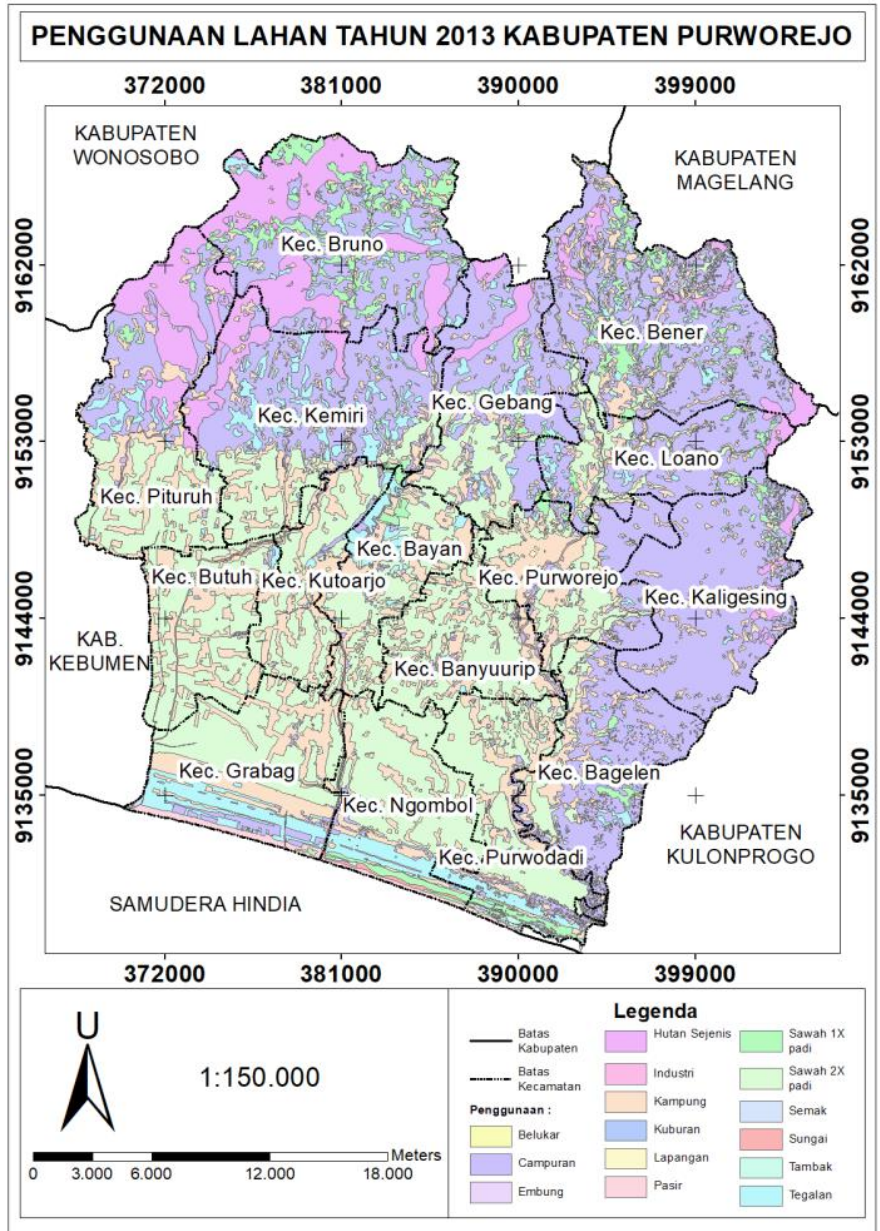

(B)

Gambar 2. Peta penggunaan lahan tahun 2008 (A) dan tahun 2013 (B) (Sumber: Hasil pengolahan data) 


\section{Data editing}

Pengolahan data yang dilakukan pertama kali adalah melakukan pengecekan terhadap data, yaitu data penggunaan lahan tahun 2008 dan tahun 2013, data administrasi Kabupaten Purworejo, dan data rencana tata ruang wilayah Kabupaten Purworejo tahun 2011-2031. Pengecekan pertama adalah kesesuaian sistem referensi yang digunakan untuk memastikan bahwa semua data spasial memiliki sistem referensi spasial yang sama. Selanjutnya dilakukan pengecekan topologi. Hal ini dilakukan untuk memastikan bahwa topologi peta sudah terbangun dengan baik. Proses ini dilakukan melalui tahapan pembangunan topologi, yaitu dilakukan dengan menambahkan beberapa topology rules. Topology rules yang digunakan di antaranya adalah (1) tidak adanya penggunaan lahan yang tumpang tindih (must not overlap) karena antar poligon lahan tidak diperbolehkan saling tumpang tindih, dan (2) tidak diperbolehkan adanya gap antara poligon lahan satu dengan poligon tetangga (must not have gaps). Hal yang sama dilakukan pada data penggunaan lahan 2013 dan data RTRW. Pengecekan yang ketiga adalah pengecekan atribut pada tiap-tiap peta, untuk memastikan bahwa atribut yang ada tidak kosong, salah, atau tidak sesuai dengan data spasialnya.

\section{Data processing}

Pemrosesan data dilakukan menggunakan metode analisis spasial berupa overlay. Data masukan yang digunakan yaitu data penggunaan lahan tahun 2008 dan 2013. Hasil dari proses yang telah dilakukan adalah satu data baru dalam format shapefile yang berisi gabungan dari data penggunaan lahan tahun 2008 dan 2013. Data tersebut digunakan untuk mengetahui daerah perubahan dan luasan perubahan penggunaan lahan yang terjadi. Metode yang sama dilakukan untuk mengevaluasi kesesuaian antara data penggunaan lahan tahun 2013 dan RTRW. Hal ini bertujuan untuk mendapatkan hasil kesesuaian antara penggunaan lahan terhadap peruntukannya. Hasil proses overlay yaitu perubahan penggunaan lahan tahun 2008 sampai dengan tahun 2013 yang informasinya berada dalam satu data berformat shapefile dan kesesuaian penggunaan lahan dengan Rencana Tata Ruang Wilayah. Kemudian dari hasil tersebut dilakukan analisis.

\section{Analisis perubahan dan kesesuaian}

Analisis perubahan penggunaan lahan dan kesesuaian dengan RTRW dilakukan pada unit kecamatan. Untuk itu, maka dilakukan pemotongan untuk setiap wilayah kecamatan yang ada di Kabupaten Purworejo. Data hasil ekstraksi per wilayah kecamatan ini kemudian diolah menggunakan metode statistik untuk mengetahui besaran perubahan penggunaan lahan serta besaran kesesuaian penggunaan lahan dengan RTRW. Analisis kesesuaian didasarkan pada Neraca Penatagunaan Tanah (NPGT). Terdapat dua kelas kesesuaian penggunaan lahan, yaitu :

1. Sesuai: apabila penggunaan tanah yang ada sesuai dengan arahan pola ruang.

2. Tidak sesuai: apabila penggunaan tanah tidak

\section{Hasil dan Pembahasan}

3.1. Perubahan Penggunaan Lahan Tahun 2008-2013 di Kabupaten Purworejo

Perubahan penggunaan lahan Kabupaten Purworejo dari tahun 2008 - 2013 disajikan dalam bentuk grafik persentase luas perubahan (Gambar 3), informasi detil perubahan penggunaan lahan (Tabel 1), dan peta perubahan penggunaan lahan (Gambar 4).

Seperti tersaji pada Gambar 3, luas perubahan penggunaan lahan paling besar terjadi di Kecamatan Grabag sebesar $258.08 \mathrm{Ha}$ atau sebesar 38,03\%, disusul oleh Kecamatan Bayan dengan luas 203.62 Ha atau sebesar 30\%, Kecamatan Kemiri dengan luas 96.14 Ha atau sebesar $14,17 \%$, serta Kecamatan Kutoarjo dengan luas $87.93 \mathrm{Ha}$ atau sebesar 12,96\%. Keempat kecamatan tersebut adalah kecamatan yang mengalami perubahan penggunaan lahan terbesar dengan nilai perubahan di atas $12 \%$.

Selain keempat kecamatan tersebut, 7 kecamatan yang lain hanya mengalami perubahan penggunaan lahan yang relatif kecil, dengan nilai peresntasi perubahan di $0,02 \%$ hingga $1,77 \%$, contohnya adalah Kecamatan Purwodadi dengan luas $11.98 \mathrm{Ha}$ atau sebesar 1,77\%, Kecamatan Banyuurip dengan luas $8.06 \mathrm{Ha}$ atau sebesar $1,19 \%$, Kecamatan Butuh dengan luas $4.79 \mathrm{Ha}$ atau sebesar 0,71\%, Kecamatan Purworejo dengan luas $3.95 \mathrm{Ha}$ atau sebesar 0,58\%, Kecamatan Bagelen dengan luas 2.19 Ha atau sebesar 0,32\%, Kecamatan Pituruh dengan luas 1.76 Ha atau sebesar 0,26\%, Kecamatan Kaligesing dengan luas $0.14 \mathrm{Ha}$ atau sebesar $0,02 \%$. Sisanya adalah 4 kecamatan yang tidah mengalami perubahan penggunaan lahan, yaitu Kecamatan Bruno, Kecamatan Ngombol, Kecamatan Bener, Kecamatan Gebang, dan Kecamatan Loano.

Untuk memahami perubahan penggunaan lahan lebih detil, khususnya di Kecamatan Grabag yang merupakan kecamatan yang mengalami perubahan penggunaan lahan tertinggi, dapat dilihat pada Tabel 1. DI Kecamatan Grabag, perubahan penggunaan lahan terbesar terjadi pada penggunaan tanah tegalan menjadi sawah seluas 351.34 $\mathrm{Ha}$, yang disusul oleh penggunaan tanah kebun yang berubah menjadi penggunaan tanah tanaman campuran seluas 250.71 Ha. Jika melihat data perubahan tersebut yang didominasi oleh perubahan dari penggunaan tegalan menjadi sawah dan kebun menjadi campuran, maka dapat ditarik kesimpulan bahwa perubahan penggunaan lahan di Kecamatan Grabag didominasi oleh penggunaan lahan untuk pertanian. Perubahan penggunahaan lahan dari tegalan, sawah, tegalan dan campuran bisa jadi terjadi secara musiman, sesuai dengan iklim dan musim tanam. Oleh karena itu bisa dikatakan bahwa perubahan penggunaan lahan ini sfatnya tidak permanen.

Namun demikian, ada jenis perubahan lahan yang sifatnya lebih permanen, yaitu perubahan penggunaan lahan dari campuran mejadi kampung sebesar $12.37 \mathrm{Ha}$, perubahan dari sawah menjadi kampung atau pemukiman seluas $23.38 \mathrm{Ha}$, perubahan dari tegalan menjadi kampung 
dan industri masing-masing seluas $0.63 \mathrm{Ha}$ dan $0.43 \mathrm{Ha}$, serta dari kampung menjadi industri seluas $0.81 \mathrm{Ha}$. Perubahan dari sawah dan campuran menjadi kampung disinyalir disebabkan karena tuntutan pemukiman bagi masyarakat di Kecamatan Grabag. Selain itu, pertumbuhan industri juga terlihat dari perubahan [enggunaan lahan dari kampung dan tegalan menjadi industri, dengan luas total $1.24 \mathrm{Ha}$.

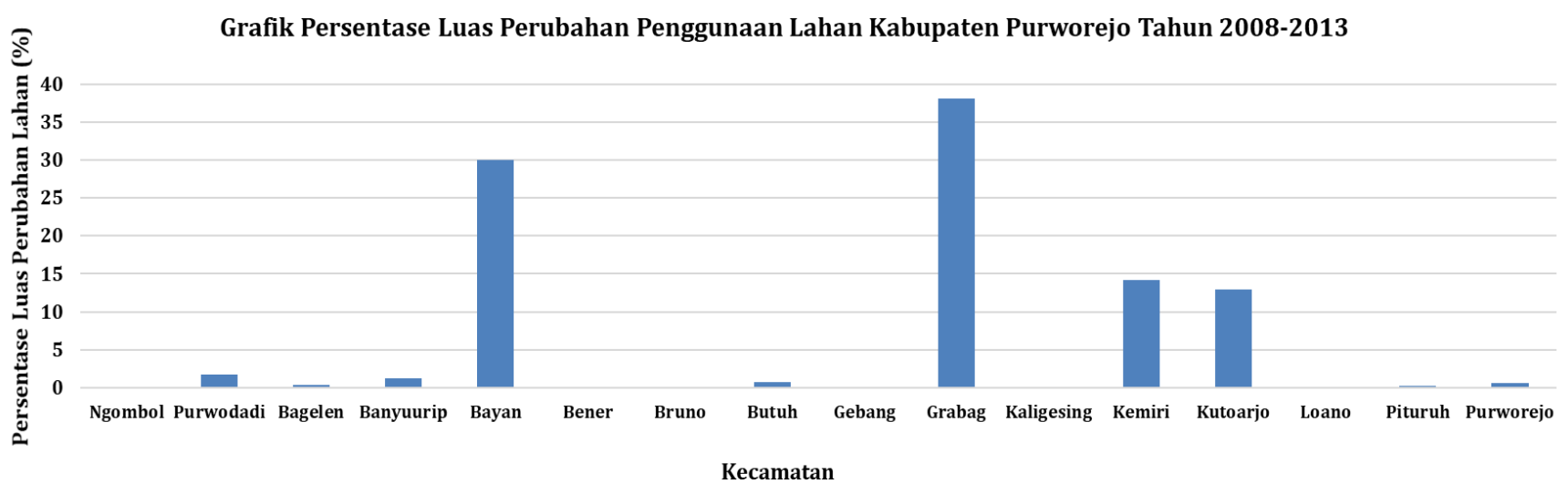

Gambar 3. Grafik Persentase Luas Perubahan Pengggunaan Lahan di Kabupaten Purworejo Tahun 2008-2013

Peta perubahan penggunaan lahan Kecamatan Grabag ditunjukkan pada Gambar 4. Dari peta tersebut terlihat bahwa perubahan penggunaan lahan terjadi dibagian selatan wilayah Kecamatan Grabag. Hal ini barangkali sesuai dengan Peraturan Daerah Kabupaten Purworejo Nomor 11 Tahun 2004 Tentang Kawasan Bahari Terpadu
(KBT) Kabupaten Purworejo, di mana Kecamatan Grabag merupakan salah satu kecamatan yang dikembangkan untuk Kawasan Bahari Terpadu, sehingga pertumbuhan wilayah banyak terjadi di wilayah bagian selatan dekat dengan pantai.

Tabel 1. Perubahan Penggunaan Lahan di Kabupaten Purworejo.

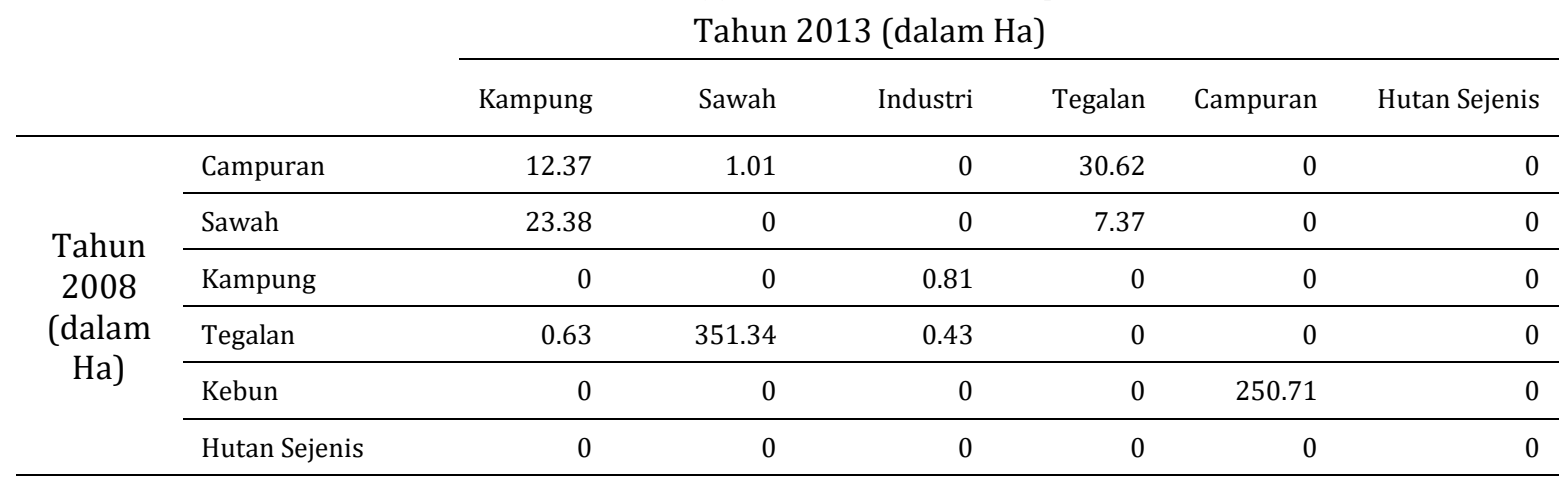

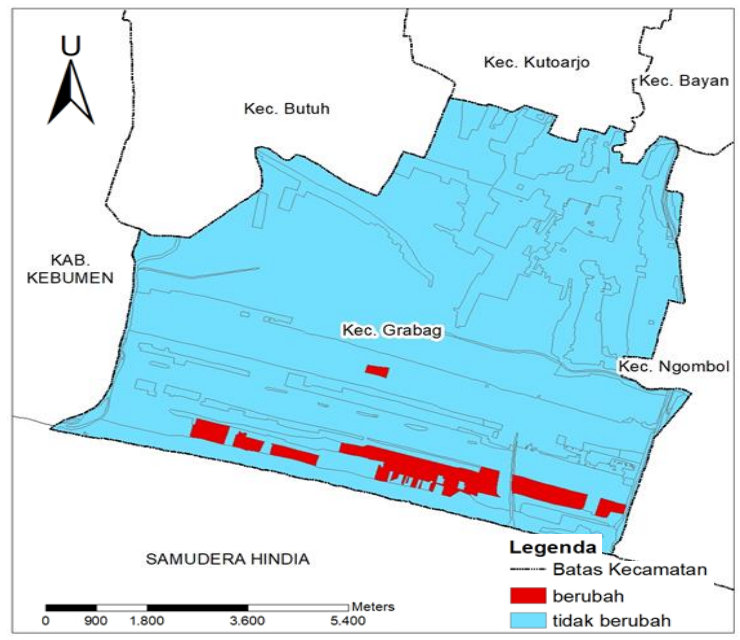

Gambar 4. Perubahan Penggunaan Lahan di Kecamatan Grabag (Sumber: BPN Purworejo dan hasil pengolahan data)
3.2. Kesesuaian antara Penggunaan Lahan Tahun 2013 terhadap RTRW Kabupaten Purworejo

Penggunaan lahan di Kabupaten Purworejo telah diatur dalam Rencana Tata Ruang Wilayah (RTRW) Kabupaten Purworejo tahun 2011 - 2031, kenyataannya pada tahun 2013 masih terdapat penggunaan lahan yang belum sesuai dengan peruntukannya di RTRW. Secara keseluruhan penggunaan lahan Kabupaten Purworejo tahun 2013 sesuai peruntukannya sebesar 62,21\%. Grafik persentase kesesuaian penggunaan lahan terhadap peruntukannya di Kabupaten Purworejo per kecamatan ditunjukkan pada Gambar 5.

Kesesuaian antara penggunaan lahan dan RTRW yang terjadi untuk setiap kecamatan-kecamatan di Kabupaten Purworejo adalah sebagai berikut :

a). Kecamtan Butuh.

Persentase kesesuaian Kecamatan Butuh sebesar 91,73\%. Peruntukan lahan yang sama sekali tidak 
sesuai adalah peruntukan lahan perkebunan. Peruntukkan lahan yang sesuai antara lain lahan pemukiman, sawah, sempadan sungai, dan sungai.

b). Kecamatan Banyuurip.

Persentase kesesuaian Kecamatan Banyuurip sebesar 90,44\%. Peruntukan lahan yang sama sekali tidak sesuai adalah peruntukan lahan perkebunan dan sempadan mata air. Adapun peruntukkan lahan yang sesuai antara lain pemukiman, sawah, sempadan sungai, dan sungai.

c). Kecamatan Ngombol.

Persentase kesesuaian Kecamatan Ngombol sebesar $84,11 \%$. Peruntukan lahan yang sama sekali tidak sesuai adalah peruntukan lahan hutan lindung, hutan produksi, industri, perkebunan, dan sempadan embung. Adapun peruntukan lahan yang sesuai antara lain lahan yang permukiman, sawah, sempadan pasir, sempadan sungai dan sungai.

d). Kecamatan Bayan.

Persentase kesesuaian Kecamatan Bayan sebesar 81,81\%. Peruntukan lahan yang sama sekali tidak sesuai adalah peruntukan lahan industri, perkebunan, dan sempadan mata air. Peruntukkan lahan yang sesuai antara lain lahan yang dikelola masyarakat, pemukiman, sawah, sempadan sungai, dan sungai.

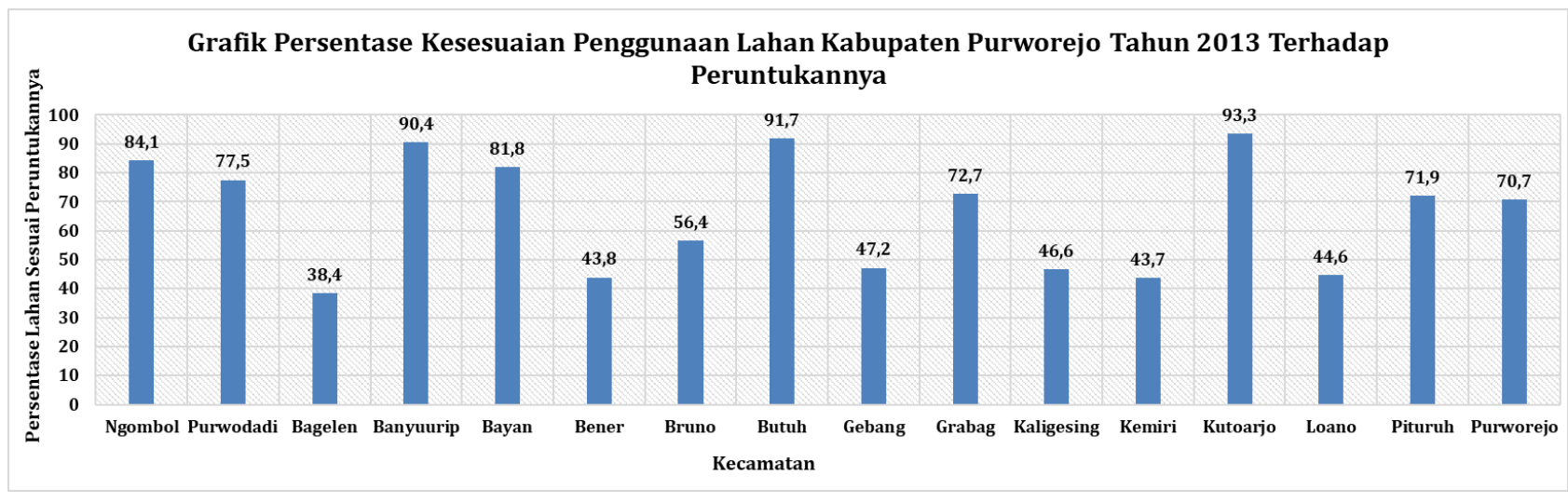

Gambar 5. Grafik Persentase Penggunaan Lahan Kabupaten Purworejo Tahun 2013 Terhadap Peruntukannya

e). Kecamatan Purwodadi.

Persentase kesesuaian Kecamatan Purwodadi sebesar 77,45\%. Peruntukan lahan yang sama sekali tidak sesuai adalah peruntukan lahan hutan lindung, hutan produksi, industri, perkebunan, dan sempadan embung. Adapun peruntukkan lahan yang sesuai antara lain lahan permukiman, sawah, sempadan pantai, sempadan sungai, dan sungai.

f). Kecamatan Grabag.

Persentase kesesuaian Kecamatan Grabag sebesar $72,75 \%$. Peruntukan lahan yang sama sekali tidak sesuai adalah peruntukan lahan hutan lindung, hutan produksi, dan sempadan embung. Peruntukan lahan yang sesuai antara lain lahan industri, pemukiman, sawah, sempadan pantai, sempadan sungai, dan sungai.

g). Kecamatan Pituruh.

Persentase kesesuaian Kecamatan Pituruh sebesar $71,94 \%$. Peruntukan lahan yang sama sekali tidak sesuai adalah peruntukan lahan perkebunan dan sempadan embung. Adapun peruntukan lahan yang sesuai antara lain lahan yang dikelola masyarakat, hutan produksi, permukiman, sawah, sempadan sungai, dan sungai.

h). Kecamatan Purworejo.

Persentase kesesuaian Kecamatan Purworejo sebesar 70,71\%. Peruntukan lahan yang sama sekali tidak sesuai adalah peruntukan lahan perkebunan, sempadan embung, sempadan mata air, dan tambang non logam. Adapun peruntukkan lahan yang sesuai antara lain lahan yang dikelola masyarakat, permukiman, sawah, sempadan sungai, dan sungai.

i). Kecamatan Bruno.

Persentase kesesuaian Kecamatan Bruno sebesar $56,41 \%$. Peruntukan lahan yang sama sekali tidak sesuai adalah peruntukan lahan perkebunan, sempadan embung, dan tambang non logam. Adapun peruntukkan lahan yang sesuai antara lain lahan yang dikelola masyarakat, hutan produksi, pemukiman, sawah, sempadan sungai, dan sungai.

j). Kecamatan Gebang.

Persentase kesesuaian Kecamatan Gebang sebesar 47,15\%. Peruntukan lahan yang sama sekali tidak sesuai adalah peruntukan lahan bendungan Bener, perkebunan, dan sempadan embung. Peruntukan lahan yang sesuai antara lain lahan yang dikelola masyarakat, hutan produksi, pemukiman, sawah, sempadan sungai, dan sungai.

k). Kecamatan Kaligesing.

Persentase kesesuaian Kecamatan Kaligesing sebesar 46,58\%. Peruntukan lahan yang sama sekali tidak sesuai adalah peruntukan lahan Kawasan lindung karst, perkebunan, sempadan embung, dan tambang non logam. Peruntukan lahan yang sesuai antara lain lahan yang dikelola masyarakat, hutan produksi, pemukiman, 
sawah, sempadan sungai, dan sungai.

1). Kecamatan Loano.

Persentase kesesuaian Kecamatan Loano sebesar 44,62\%. Peruntukan lahan yang sama sekali tidak sesuai adalah peruntukan lahan perkebunan, sempadan embung, dan sempadan mata air. Adapun peruntukkan lahan yang sesuai antara lain lahan yang dikelola masyarakat, hutan produksi, permukiman, sawah, sempadan sungai, dan sungai.

m).Kecamatan Bener.

Persentase kesesuaian Kecamatan Bener sebesar 43,84\%. Peruntukan lahan yang sama sekali tidak sesuai adalah peruntukan lahan bendungan, perkebunan, sempadan embung, sempadan mata air, dan tambang non logam. Adapun peruntukkan lahan yang sesuai antara lain lahan yang dikelola masyarakat, hutan produksi, pemukiman, sawah, sempadan sungai, dan sungai.

n). Kecamatan Kemiri.

Persentase kesesuaian Kecamatan Kemiri sebesar 43,68\%. Peruntukan lahan yang sama sekali tidak sesuai adalah peruntukan lahan perkebunan.

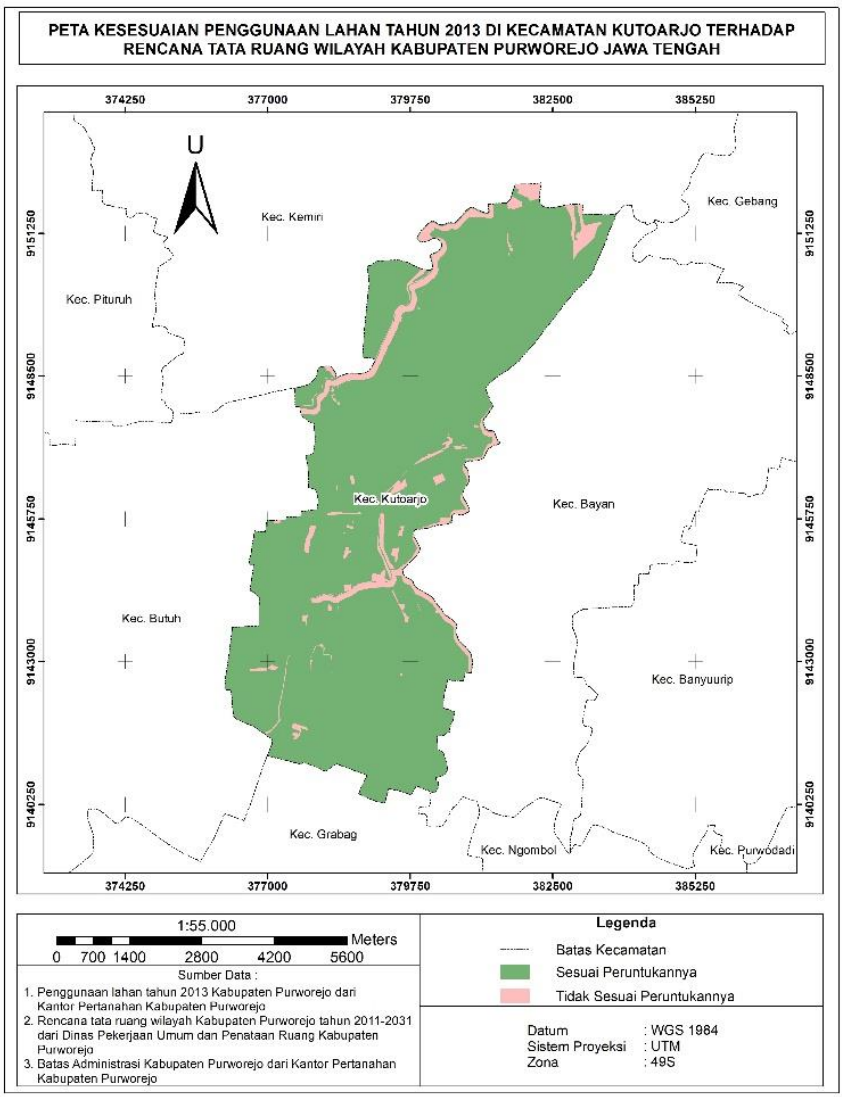

(A)
Peruntukkan lahan yang sesuai antara lain lahan yang dikelola masyarakat, embung, hutan produksi, pemukiman, sawah, sempadan embung, sempadan sungai, dan sungai.

o). Kecamatan Kutoarjo.

Kecamatan Kutoarjo dengan persentase kesesuaian penggunaan lahan terhadap peruntukannya sebesar93,34\% merupakan kecamatan dengan persentase terbesar penggunaan lahan yang sesuai peruntukkannya. Peruntukan lahan yang sama sekali tidak sesuai di Kecamatan Kutoarjo adalah peruntukan lahan perkebunan sebesar 1,35\%. Adapun peruntukkan lahan yang sesuai antara lain lahan yang dikelola masyarakat pemukiman, sawah, sempadan sungai, dan sungai. Terdapat ketidaksesuaian sebesar 0,36\% pada peruntukan lahan pemukiman, $1,5 \%$ pada peruntukan lahan sawah, 2,65\% pada peruntukan lahan sempadan sungai, dan $0,8 \%$ pada peruntukan lahan sungai. Total ketidaksesuaian penggunaan lahan terhadap peruntukannya sebesar 6,65\%. Peta kesesuaian penggunaan lahan di Kecamatan Kutoarjo terhadap peruntukannya ditunjukkan pada Gambar 6 .

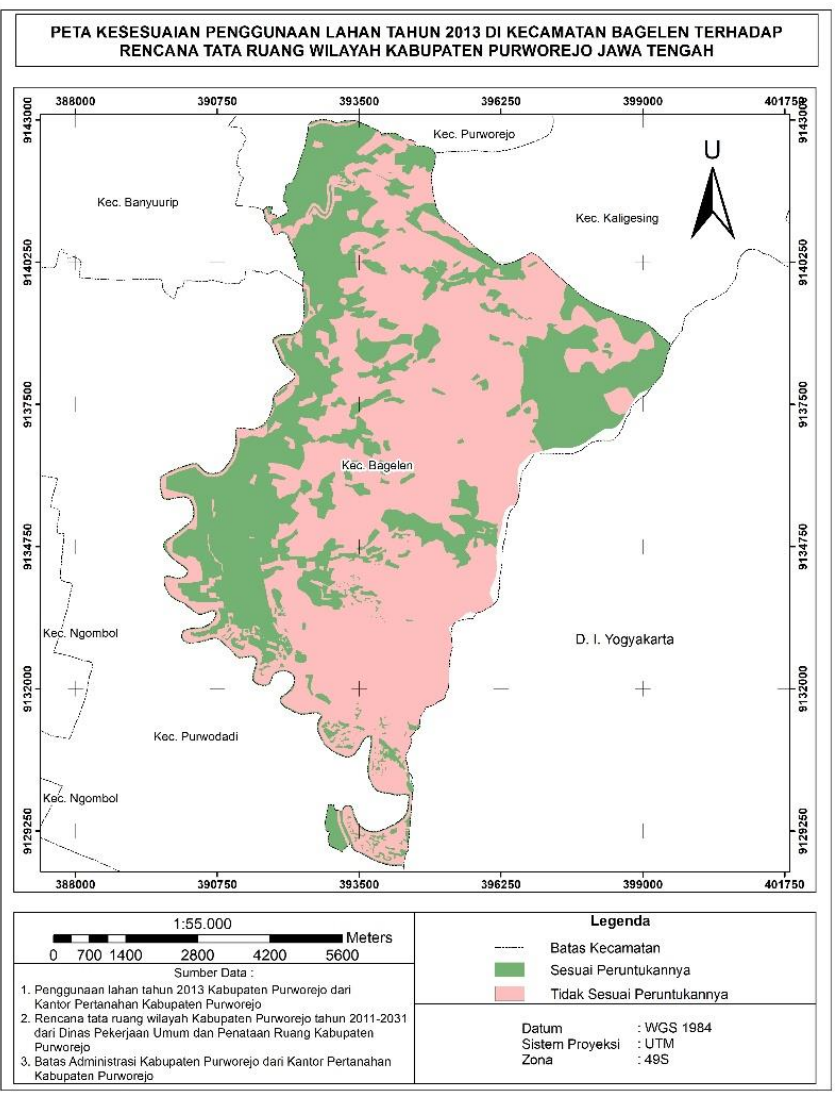

(B)

Gambar 6. Peta Kesesuaian Penggunaan Lahan Tahun 2013 terhadap RTRW: Kecamatan Kutoarjo (A); Kecamatan Bagelen (B) 
p). Kecamatan Bagelen

Kecamatan Bagelen dengan persentase kesesuaian penggunaan lahan terhadap peruntukannya sebesar $38,40 \%$ merupakan kecamatan dengan persentase kesesuaian penggunaan lahan terhadap peruntukannya yang terkecil. Peruntukan lahan yang sama sekali tidak sesuai di Kecamatan Bagelen adalah peruntukan lahan perkebunan sebesar 38,31\%, sempadan embung sebesar $0,2 \%$, dan tambang logam sebesar 5,03\$. Adapun peruntukkan lahan yang sesuai di Kecamatan Bagelen antara lain lahan yang dikelola masyarakat, pemukiman, sawah, sempadan sungai, dan sungai. Terdapat ketidaksesuaian pada peruntukan lahan pemukiman sebesar 3,96\%, sawah sebesar 11,18\%, sempadan sungai sebesar 2,74\%, dan sungai sebesar $0,18 \%$. Total ketidaksesuaian penggunaan lahan di Kecamatan Bagelen terhadap peruntukannya sebesar $61,6 \%$. Peta kesesuaian penggunaan lahan di Kecamatan Bagelen terhadap peruntukannya ditunjukkan pada Gambar 6.

\section{Kesimpulan}

Analisis perubahan penggunaan lahan dan kesesuaiannya di Kabupaten Purworejo tahun 2008 sampai 2013, telah berhasil dilakukan dan menghasilkan perubahan lahan serta kesesuaiannya yang disajikan dalam bentuk tabel, grafik, dan peta. Hasil dari penelitian ini menunjukkan bahwa terdapat perubahan penggunaan lahan pada tahun 2008 sampai 2013 dan terdapat ketidaksesuaian terhadap RTRW. Oleh karena itu, perlu dilakukan penelitian serupa pada tahun 2018 untuk mengetahui perubahan penggunaan lahan yang terjadi dan kesesuaiannya terhadap RTRW.

Kabupaten Purworejo secara keseluruhan mengalami perubahan penggunaan lahan sebesar $0,1 \%$ dari seluruh wilayah Kabupaten Purworejo. Seluruh kecamatan di Kabupaten Purworejo pada tahun 2008-2013, mengalami perubahan penggunaan lahan kurang dari 40\% untuk masing-masing kecamatannya. Luas perubahan penggunaan lahan paling besar terjadi di Kecamatan Grabag dengan persentase $0,71 \%$ dari seluruh wilayah Kecamatan Grabag. Semntara itu, kecamatan yang tidak mengalami perubahan penggunaan lahan adalah di Kecamatan Bruno, Kecamatan Ngombol, Kecamatan Bener, Kecamatan Gebang, dan Kecamatan Loano.

Secara keseluruhan penggunaan lahan Kabupaten Purworejo tahun 2013 sesuai peruntukannya sebesar $62,21 \%$ dari seluruh wilayah Kabupaten Purworejo. Kecamatan Kutoarjo merupakan kecamatan dengan persentase terbesar penggunaan lahan sesuai peruntukkannya yaitu sebesar 93,34 \% dari seluruh wilayah Kecamatan Kutoarjo. Kecamatan Bagelen merupakan kecamatan dengan persentase terkecil penggunaan lahan sesuai peruntukannya yaitu sebesar $38,40 \%$ dari seluruh wilayah Kecamatan Bagelen.

\section{Referensi}

Aditya, T., Maria-Unger, E., Berg, C., Bennett, R., Saers, P., Syahid, H. L., Erwan, D., Wits, T., Widjajanti, N., Santosa, P. B., Atunggal, D., Hanafi, I., dan Sutejo, D. (2020). Participatory Land Administration in Indonesia: Quality and Usability Assessment. Land. 9(3), 79. https://doi.org/10.3390/land9030079

Adiyaksa, F. \& Nugroho, P. D. (2020). Evaluasi Alih Fungsi Lahan Pertanian Menjadi Lahan Industri di Kabupaten Kendal Tahun 2014 - 2018. JGISE: Journal of Geospatial Information Science and Engineering Vol. 3, No.1, (2020), pp.71-78 https://doi.org/10.22146/jgise.55519

Al-Vatia, T. V. \& Djojomartono, P. N. (2019). Analysis of the Effect of Land Use Planning and Land Value in Gamping Subdistrict, Sleman, D.I Yogyakarta from 2013 to 2018. Journal of Geospatial Information Science and Engineering, Vol. 2 No. 2 (2019). doi:10.22146/jgise.51076

Aronoff, S. (1989). Geographic information systems: a management perspective. Canada: WDL Applications.

Astrisele, A dan Santosa, P. B. (2019). Estimating Land Value Change Post Land Consolidation of Gadingsari Village, Bantul Regency, Special Region of Yogyakarta, Indonesia. Journal of Geospatial Information Science and Engineering, Vol. 2 No. 2 (2019). https://doi.org/10.22146/jgise.51309

Handayani, R. (2013). Evaluasi Penggunaan Lahan di Kecamatan Bantul Berdasarkan Rencana Tata Ruang Wilayah. Universitas Gadjah Mada.

Iskandar, F., Awaluddin, M., dan Yuwono, B. D. (2016). Analisis Kesesuaian Penggunaan Lahan terhadap Rencana Tata Ruang/Wilayah di Kecamatan Kutoarjo Menggunakan Sistem Informasi Geografis. Jurnal Geodesi Undip. 5(1).

Kementerian Agraria dan Tata Ruang Badan Pertanahan Nasional. (2018). Tata Cara Kerja Penyusunan Neraca Penatagunaan Tanah Kecamatan.

Khadiyanto, P. (2005). Tata Ruang Berbasis pada Kesesuaian Lahan. Semarang: Badan Penerbit Universitas Diponegoro.

Kusrini, Suharyadi, dan Hardoyo, S. R. (2011). Perubahan Penggunaan Lahan Dan Faktor Yang Mempengaruhinya Di Kecamatan Gunungpati Kota Semarang. Majalah Geografi Indonesia, 25(1), hal. 2542. https://doi.org/10.22146/mgi.13358

Kusumasari, R. D. (2015). Evaluasi Kesesuaian Perubahan Penggunaan Tanah Tahun 2008 -2013 Terhadap Rencana Tata Ruang Wilayah Kabupaten Kulon Progo. Universitas Gadjah Mada.

Pangulu, M. (2016). Evaluasi Perubahan Penggunaan Lahan di Kota Bandung Tahun 2012 - 2015. Universitas Gadjah Mada.

Pemerintah Kabupaten Purworejo. (2011). Rencana Pembangunan Jangka Menengah Daerah (RPJMD) Kabupaten Purworejo Tahun 2011-2015. 
Pemerintah Kabupaten Purworejo. (2018). Rencana Kinerja Tahunan (RKT) Kabupaten Purworejo Tahun 2018.

Prabowo, H. L. (2019). Study of parcels-based Land Use Planning in Urban areas dan Rural Areas (Case Study of Mantrijeron Sub-district, Yogyakarta City and Bambanglipuro Sub-district, Bantul Regency). Journal of Geospatial Information Science and Engineering, Vol. 2 No. 1 (2019). https://doi.org/10.22146/jgise.41848

PT. Firama Citra Utama. (2003). Laporan Analisa Penyusunan Kembali Rencana Umum Tata Ruang Wilayah Kabupaten Purworejo. http://perpustakaan.bappenas.go.id/lontar/file?file =digital/12998-[_Konten_]-Konten\%20C2321.pdf (Diunduh tanggal 20 Agustus 2018).

Santosa, P. B. (2016). Evaluation of satellite image correction methods caused by differential terrain illumination. Jurnal Forum Geografi. Vol. 30, No. 1 (2016). doi:10.23917/forgeo.v30i1.1768

Saputra, V. A. (2019). Analisis Perubahan Penggunaan Lahan Tahun 2008 - 2013 dan Kesesuaiannya Terhadap RTRW Kabupaten Purworejo Tahun 20112031. Universitas Gadjah Mada.

Syafitri, A. K.N. dan Santosa, P. B. (2020). Spatial Analysis Of Kulon Progo District Development From 20072030 With Cellular Automata Markov Model. Proceeding The 1st International Conference on Geodesy, Geomatics, and Land Administration 2019. KnE Engineering Publishing. doi:10.18502/keg.v4i3.5864 